Is the afternoon, Dr. W. Krumbhaar, director of the corresponding German organisation, Institut für Lackforschung, Berlin, gave two interesting addresses on the subjects "No Illusions about Chlorinated Rubber" and "Commercial and Scientific Activities of the Paint Industry in England and Germany", to a large audience in the library at the Research Station. Among the many points of technical interest dealt with by Dr. Krumbhaar was his reference to the fact that, in Germany, a scientific man is regarded as having at least as much business acumen and ability as has his non-scientific confrère. It was evident from Dr. Krumbhaar's description of the activities of his own Institute that, in addition to carrying out a wide range of scientific investigation, a considerable amount of effort is expended in educating the German paint and varnish industry as to the details of various government restrictive orders and in protecting them from the evil effects of misuse of the patent system by large suppliers of their raw materials.

\section{Leverhulme Research Fellowships}

By the will of the first Lord Leverhulme, who died in 1925, the income arising from a part of his estate is to be devoted to the provision of scholarships for "research and education". The trustees have now resolved to devote $£ 12,000$ a year to the establishment of a scheme of research fellowships. The fellowships are primarily intended to assist experienced research workers rather than workers in an early stage of their careers. The duration of the grant will normally not exceed two years. Fellows may work either at home or abroad and no subject of inquiry is excluded from the scope of the scheme. The advisory committee is constituted as follows : Dr. H. J. W. Hetherington (chairman), Prof. A. M. Carr-Saunders, Sir William Hardy, Dr. N. V. Sidgwick, and Mr. H. T. Tizard. Dr. L. Haden Guest has been appointed secretary. Applications (from British-born candidates normally resident in the United Kingdom) and all inquiries and communications in connexion with the scheme should be addressed to the Secretary, Leverhulme Fellowship Scheme, Union House, St. Martin's-leGrand, London, E.C.1. It will be a convenience to the committee if as many applications as possible are in the hands of the secretary by June 19 .

\section{Recent Acquisitions of the British Museum(Natural History)}

ACQUISITIONs for the Department of Zoology include a series of elephant skulls from the Gola Forest, Sierra Leone, the gift of His Excellency the Governor of Sierra Leone. These skulls are of great scientific value as they demonstrate the existence of a small race of elephant in West Africa. Dr. G. H. Rodman has presented a series of stereoscopic radiographs of Mollusca shells for exhibition. Among the donations to the Department of Geology is a large collection from Miss M. S. Johnston, mainly of Silurian fossils from England and Norway. A portion of a meteoric stone which fell on July 8, 1932, at Kahrapar, Jaunpur, United Provinces, India, has been presented to the Department of Minerals by Mr. $\mathrm{H}$. Minson. A collection of Coleoptera belonging to the family Curculionidæ and numbering approximately 40,000 specimens, has been deposited in the Department of Entomology as a "permanent loan" by the Hawaiian Sugar-planters' Association of Honolulu. The collection, which is representative of the weevils of every part of the world, was brought together by the late Dr. David Sharp, after his first and largest collection of beetles had been acquired by the Museum in 1905. His British collection was acquired in 1932 .

THE Department of Botany has had bequeathed to it the herbarium of Mr. James Groves, who was the recognised authority on Charophyta (stoneworts) and one of the best-known field botanists of Great Britain. He worked for many years in collaboration with his brother Henry, and together they edited the ninth edition of Babington's "Manual of British Botany". Henry died in 1912 and in 1918 a first consignment $(6,000)$ of their British plants was presented to the Department. James later wrote the Ray Society's monograph on Charophyta with Canon Bullock Webster as joint author. The bequest in. cludes more than 6,000 Charophyta and about 11,000 British flowering plants : the remainder are mosses and sea-weeds. All are well and carefully mounted ready to be incorporated in the herbarium. Dr. R. J. D. Graham, of the University of Edinburgh, has presented his collection of about 1,300 Mesopotamian plants made by himself and others. An account of the plants will appear shortly in "Notes from the Royal Botanic Garden, Edinburgh". The Sladen and Godman Trusts have presented about 900 plants recently collected on the Islands of the Gulf of Guinea by Mr. A. W. Exell, assistant keeper in the Department, in company with Mr. W. H. T. Tams, of the Department of Entomology. The islands visited were Fernando Po, Principe, Săo Thomé and Annobon, from which there was little material previously in the herbarium. The collections from Fernando Po were practically confined to the Inoka region in the south, a country with a most interesting vegetation unique in tropical Africa. There are many now records of plants and several new species. The collections will probably enable a general account of the geographical relationships of the four islands to be written.

\section{Chemistry and the Art of Living}

ON March 24 Prof. H. E. Armstrong delivered the Sir Jesse Boot Foundation lecture in the lecture theatre of University College, Nottingham. Recalling the fact that one of the most pleasant memories of his life was the hours spent under the roof of Sir Jesse and Lady Boot, he paid tribute to the quality that belonged to his late host and claimed that, in founding the chair of chemistry, Sir Jesse Boot did a service to his fellow citizens which will ultimately save them from themselves: providing they be taught the proper art of living, which will soon be the duty of chemistry. When this is achieved, "cash chemists" may cease to exist, as drugs are only used to counteract inborn faults in the human machine and insufficient food, deficiencies in food, effects of over-feeding or improper feeding, zymotic disease. 
Hence the future lies with the farmer, who will have to produce not only the food that we desire but also that which we ought to have in a perfect condition. To do this, the farmer will have to feed his animals properly and this necessitates a great extension in the use of fertilisers on the land. Thus it appears that the "cash chemist" returns to action with a change of function- to supply the farmer with his chemical manures. Prof. Armstrong was despondent at the delay in reaching this condition of a brave new world and concluded with the following words : "at the moment our failure to use intelligence, the world over, is astounding-some fault there must be in developing it. A few months ago in a speech in this city I suggested clearing out the present race of students and their teachers and bringing in 500 chosen boys who could be trained as cooks. I would repeat my advice to-day but add that to cook should mean to understand what is cooked, what is fit and proper to be eaten, as well as the mere art of kitchenry. We cannot get away from the fact that we live always through our stomachs ; from these it is, through the foodwe put into them, that we gain and haveour being."

\section{Electric Welding in Ship Construction}

ELECTRIC welding, instead of rivetting, is being widely adopted in shipbuilding. In German naval dockyards it has practicaliy superseded rivetting. Electrically welded ships have practically no leakage and there is little corrosion or wastage of plates around the welded joints. Economies are effected by welding in the weight and cost of a ship's hull. The welded ship therefore yields greater service for a smaller investment of capital. The University of Glasgow has introduced welding work into its laboratories and the design of welding joints has been introduced into all its engineering courses. The Glasgow Education Committee is also taking steps to form a new skilled class of workmen called ship welders. Before a change of this kind can be made it is necessary for the employers and the trade unions to meet. In the Times of May 26 an account is given of a conference held in Edinburgh between employers' federations and trade unions on this subject. Mr. J. B. Hutchison, the chairman of the employers, stated that it is of the greatest importance that the development of welding should proceed as rapidly and smoothly as possible in Great Britain on economical lines in order that competition with other shipbuilding nations may be suecessfully faced. It is understood that the employers made it clear that the selection of ship welders is likely to be made from the most suitable men, not confined to any one class and not necessarily from men directly displaced by the new process. Mr. Sherwood, on behalf of the unions, said that the proposals were of such a farreaching character that full and careful consideration was necessary.

\section{Electrical Equipment of the Queen of Bermuda}

IN the G.E.C. (General Electric Co.) Journal for May there is a full and interesting description of the electrification of the Furness-Withy liner, Queen of Bermuda. It was launched at Barrow-in-Furness last February and has successfully completed its trials. Its tonnage is 22,500 and its shaft horse power is about 20,000. Electricity is used on the most extensive scale possible throughout the ship. It is used for the propulsion and steering of the ship. It is also used for lighting and ventilation, cooking, refrigeration, the handling of cargo, and there are eleven electric lifts, etc., the auxiliary machinery totalling about 3,000 horse power. For maintaining a supply of power adequate for essential services in cases of emergency, an oil-engine-driven dynamo of 50 kilowatts capacity is installed on one of the upper decks well above the water line. The change over of the panic-lighting circuits from the emergency busbars to a battery is entirely automatic and takes place on the failure of the supply voltage. The vessel is intended primarily for service between New York and Bermuda but she has been constructed for ocean-cruising as well. In view of the large amount of perishable foodstuffs which have to be carried, extensive refrigerating plant is provided. For this purpose, 23 motors are required, the largest being of 70 horse power for driving a carbon dioxide compressor. The lighting is done on a very lavish scale, requiring 450 kilowatts of electric energy. It is mainly effected by concealed lighting in opaque cornices, diffused lighting through continuous glazed cornices, or box lights glazed with tinted diffusing glasses in modern designs. For illuminating the dancing space three-colour lighting is used for the main ceiling. The lights are controlled by dimmers when dancing is in progress so as to produce a pleasing variation in the colour of the illumination. This is a great improvement on jazz' lighting.

\section{Freshwater Biological Association}

The annual general meeting of the Freshwater Biological Association of the British Empire was held on May 11 in the rooms of the British Waterworks Association, Grand Buildings, Trafalgar Square, W.C.2. The following officers were elected for 1933-34 :--President, Mr. Reginald Beddington; Chairman of Council, Prof. F. E. Fritsch; Hon. Treasurer, Mr. Nigel O. Walker; Hon. Director of the Laboratory, Dr. W. H. Pearsall ; Hon. Secretary, Mr. J. T. Saunders. The report of the Council showed that considerable progress has been made in fitting out the Laboratory of the Association at Wray Castle at Windermere. Tables are now available for visiting research workers and accommodation for these workers is provided in the Castle. Subscriptions have been received from a wide circle interested in freshwater problems. Subscriptions, renting tables at the Laboratory, have also been received from universities, many of which have already nominated research workers to occupy their tables at the Laboratory. The Council is anxious to provide the fullest possible facilities at the Laboratory for those who wish to work on freshwater problems. The most pressing need at the moment is the provision of an electric supply for the Laboratory, but the Council has at present no funds to supply this need. The address of the honorary secretary of the Association is Mr. J. T. Saunders, Christ's College, Cambridge. 